\title{
Reversal of Setting Expansion of Gypsum-Bonded Investment Containing Admixed $\mathrm{CaSO}_{4} \cdot 2 \mathrm{H}_{2} \mathrm{O}$
}

\author{
Hisao FUKUI, Tatsushi KAWAI, Masashi KITO, Motohiko KIKUCHI \\ and Jiro HASEGAWA \\ Department of Dental Materials, School of Dentistry, Aichi-Gakuin University, 2-11 Suemori, Chikusa \\ Nagoya 464, Japan
}

Received on January 19, 1984

\begin{abstract}
Reversal or loss of setting expansion gypsum-bonded investment is studied as a function of mixing rate and $\mathrm{CaSO}_{4} \cdot 2 \mathrm{H}_{2} \mathrm{O}$ content. Investments containing $\mathrm{CaSO}_{4} \cdot 2 \mathrm{H}_{2} \mathrm{O}$ mixed at higher speeds $(1000 \mathrm{rpm}$ and $1680 \mathrm{rpm}$ ) exhibited at 24 hours reversal or loss of setting expansion which is directly related to both the speeds of mixing and $\mathrm{CaSO}_{4} \cdot 2 \mathrm{H}_{2} \mathrm{O}$ content.
\end{abstract}

Key Words: Investment, Reversal, Setting expansion.

\section{INTRODUCTION}

Gypsum-bonded investments expand while setting, and this expansion coupled with subsequent thermal expansion, provides a mold sufficiently enlarged to compensate for the shrinkage of molten alloy upon cooling from casting temperature to room temperature. Previous papers ${ }^{1,2)}$ have reported a reversal or loss of setting expansion over a $24 \mathrm{hr}$. period under certain conditions of mixing and ring configuration. The degree of reversal was positively correlated with mixing rate and powder/water ratio. Other studies ${ }^{3)}$ have shown this reversal in setting expansion to be related as well to the content of calcium sulfate dihydrate (CSD) added to the investment prior to mixing.

The purpose of this study was to investigate the combined effects of CSD content and mixing rate upon the setting expansion of a gypsum-bonded investment.

\section{MATERIALS AND METHODS}

The materials used in this study are listed in Table 1. Shofu cristobalite* investment was shown by X-ray diffraction analysis to be free of CSD. Experimental samples were produced by adding 0, 1, 2 and 3\% CSD to $100 \mathrm{~g}$. samples of Shofu cristobalite investment. All samples were prepared as $100 \mathrm{~g}$. of powder and mixed at $\mathrm{W} / \mathrm{P}$ ratio of 0.35 .

The experimental arrangement used to measure axial setting expansion in standard $0.9 \mathrm{~mm}$ thick dry asbestos ${ }^{++}$lined 18:8s.s, casting rings $(\phi 30 \mathrm{~mm}, 35 \mathrm{~mm}$ length) is shown in Figure 1.

* Shofu, Kyoto, Japan

+ Whip-Mix Corp. Louisville, Ky.

${ }^{++}$Morita Corp. Kyoto, Japan 
Table 1 Materials used and Experimental Methods

\begin{tabular}{l|l}
\hline Investment Used & $\begin{array}{l}\text { Shofu cristobalite } \\
\text { W/P ratio }\end{array}$ \\
$\mathrm{CaSO}_{4} \cdot 2 \mathrm{H}_{2} \mathrm{O}$ added & $0 \%, 1 \%, 2 \%$ and $3 \%$ \\
\hline Mixing Condition & $\begin{array}{l}\text { Hand mixing: } 15 \mathrm{sec}(120 \mathrm{rpm}) \\
\text { Mechanical (1) } 450 \mathrm{rpm} \\
\text { mixing (2) } 1000 \mathrm{rpm} 45 \mathrm{sec}\end{array}$ \\
& (3) $1680 \mathrm{rpm}$ \\
\hline
\end{tabular}

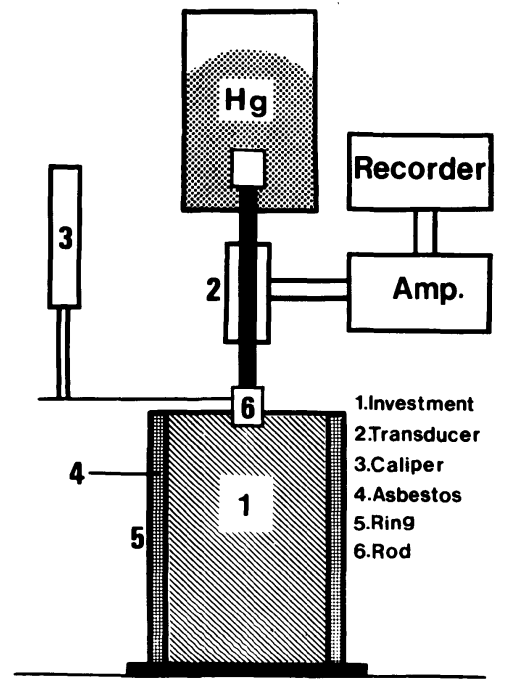

Figure 1 Apparatus for measurement of axial setting expansion

Investment samples were mechanically mixed at 450,1000 or $1680 \mathrm{rpm}$. for $45 \mathrm{sec}$. using a Vac-U-Vester ${ }^{+}$. The rings were placed as illustrated in Figure 1 upon a flat glass plate and filled with mixed investment. The glass plate and filled ring was then placed on the table of an electric dilatometer ${ }^{++}$, and a transducer bar weighing $0.5 \mathrm{~g}$. and $10 \mathrm{~mm}$ in diameter was placed $1 \mathrm{~mm}$. deep using caliper into the investment at the center of the ring.

Each setting expansion measurement was started 1 minute after commencement of spatulation, and expansion data were recorded continuously for $24 \mathrm{hrs}$. at $23^{\circ} \mathrm{C}$ and $50 \%$ relative humidity. Five samples of each mixing condition were measured for each experimental investment, and the data were averaged.

\section{RESULTS AND DISCUSSION}

The averaged data are presented in Table II and are graphically illustrated in Figures 2,3 , and 4 .

For all samples mixed at $450 \mathrm{rpm}$ : No change from the maximum setting expansion was detected over a $24 \mathrm{hr}$. period for any concentration of admixed CSD. Increasing the CSD did, however, decrease slightly the time required to attain maximum expansion $\left(T_{E-\max }\right)$ from 148 minutes for samples containing no CSD to 125 minutes for samples containing 3\% CSD (Table II; Figure 2)

For samples mixed at $1000 \mathrm{rpm}$ : The maximum setting expansion (E-max) was maintained at $24 \mathrm{hrs}$. only for those samples containing no CSD. Increasing the CSD content by 1,2 , and $3 \%$ resulted in a reversal of E-max of $0.7,4.0$, and $10.1 \%$ respective-

\footnotetext{
+ Whip-Mix Corp. Louisville, Ky.

++ Shinko-Denki Corp. Kobe, Japan
} 
Table 2 Expansion data for various $\mathrm{CaSO}_{4} \cdot 2 \mathrm{H}_{2} \mathrm{O}$ contents and mixing speeds

\begin{tabular}{|c|c|c|c|c|c|c|c|}
\hline Investment & $\begin{array}{l}\text { Mixing } \\
\text { speed } \\
(\mathrm{rpm})\end{array}$ & $\begin{array}{c}\% \mathrm{CaSO}_{4}{ }^{\circ} \\
2 \mathrm{H}_{2} \mathrm{O} \\
\text { added }\end{array}$ & $\begin{array}{l}\text { Time before } \\
\text { initial } \\
\text { setting } \\
\text { expansion } \\
\text { (min) }\end{array}$ & $\begin{array}{l}\text { Time to } \\
\text { maximum } \\
\text { setting } \\
\text { expansion } \\
\text { (min) }\end{array}$ & $\begin{array}{l}\text { Maximum } \\
\text { setting } \\
\text { expansion } \\
(\%)\end{array}$ & $\begin{array}{c}\text { Setting } \\
\text { expansion } \\
\text { after } 24 \\
\text { hours } \\
(\%)\end{array}$ & $\begin{array}{l}\% \text { decrease } \\
\text { of maximum } \\
\text { setting } \\
\text { expansion }\end{array}$ \\
\hline \multirow{12}{*}{$\begin{array}{l}\text { Shofu } \\
\text { Cristobalite } \\
\text { Investoment } \\
\text { Containing } \\
\text { no } \\
\mathrm{CaSO}_{4} \cdot 2 \mathrm{H}_{2} \mathrm{O}\end{array}$} & \multirow{4}{*}{$450 \mathrm{rpm}$} & 0 & $\begin{array}{c}7.6 \\
(0.1)\end{array}$ & $\begin{array}{l}148 \\
(5.1)\end{array}$ & $\begin{array}{c}1.49 \\
(0.05)\end{array}$ & $\begin{array}{c}1.49 \\
(0.05)\end{array}$ & 0 \\
\hline & & 1 & $\begin{array}{c}7.8 \\
(0.3)\end{array}$ & $\begin{array}{l}140 \\
(0.8)\end{array}$ & $\begin{array}{c}1.42 \\
(0.07)\end{array}$ & $\begin{array}{c}1.42 \\
(0.07)\end{array}$ & 0 \\
\hline & & 2 & $\begin{array}{c}7.3 \\
(0.2)\end{array}$ & $\begin{array}{l}130 \\
(2.6)\end{array}$ & $\begin{array}{l}1.19 \\
(0.12)\end{array}$ & $\begin{array}{c}1.19 \\
(0.12)\end{array}$ & 0 \\
\hline & & 3 & $\begin{array}{c}7.5 \\
(0.3)\end{array}$ & $\begin{array}{l}124 \\
(5.5)\end{array}$ & $\begin{array}{c}1.08 \\
(0.07)\end{array}$ & $\begin{array}{c}1.08 \\
(0.07)\end{array}$ & 0 \\
\hline & \multirow{4}{*}{$1000 \mathrm{rpm}$} & 0 & $\begin{array}{c}5.7 \\
(0.1)\end{array}$ & $\begin{array}{l}127 \\
(2.0)\end{array}$ & $\begin{array}{l}1.56 \\
(0.11)\end{array}$ & $\begin{array}{c}1.56 \\
(0.11)\end{array}$ & 0 \\
\hline & & 1 & $\begin{array}{c}5.6 \\
(0.2)\end{array}$ & $\begin{array}{l}111 \\
(6.6)\end{array}$ & $\begin{array}{c}1.36 \\
(0.03)\end{array}$ & $\begin{array}{c}1.35 \\
(0.02)\end{array}$ & $\begin{array}{c}0.71 \\
(0.63)\end{array}$ \\
\hline & & 2 & $\begin{array}{c}5.5 \\
(0.2)\end{array}$ & $\begin{array}{c}97 \\
(1.8)\end{array}$ & $\begin{array}{c}1.30 \\
(0.01)\end{array}$ & $\begin{array}{c}1.24 \\
(0.02)\end{array}$ & $\begin{array}{c}4.00 \\
(1.77)\end{array}$ \\
\hline & & 3 & $\begin{array}{c}4.5 \\
(0.3)\end{array}$ & $\begin{array}{c}87 \\
(4.2)\end{array}$ & $\begin{array}{c}1.28 \\
(0.04)\end{array}$ & $\begin{array}{c}1.15 \\
(0.04)\end{array}$ & $\begin{array}{l}10.07 \\
(1.71)\end{array}$ \\
\hline & \multirow{4}{*}{$1680 \mathrm{rpm}$} & 0 & $\begin{array}{c}4.5 \\
(0.4)\end{array}$ & $\begin{array}{l}125 \\
(0)\end{array}$ & $\begin{array}{c}1.64 \\
(0.05)\end{array}$ & $\begin{array}{c}1.64 \\
(0.05)\end{array}$ & 0 \\
\hline & & 1 & $\begin{array}{c}3.4 \\
(0.1)\end{array}$ & $\begin{array}{c}71 \\
(6.6)\end{array}$ & $\begin{array}{c}1.46 \\
(0.04)\end{array}$ & $\begin{array}{c}1.26 \\
(0.05)\end{array}$ & $\begin{array}{l}13.85 \\
(3.29)\end{array}$ \\
\hline & & 2 & $\begin{array}{c}2.9 \\
(0.1)\end{array}$ & $\begin{array}{c}54 \\
(1.0)\end{array}$ & $\begin{array}{c}1.28 \\
(0.04)\end{array}$ & $\begin{array}{c}0.72 \\
(0.05)\end{array}$ & $\begin{array}{l}43.67 \\
(3.55)\end{array}$ \\
\hline & & 3 & $\begin{array}{c}2.5 \\
(0.2)\end{array}$ & $\begin{array}{c}51 \\
(2.4)\end{array}$ & $\begin{array}{c}1.09 \\
(0.05)\end{array}$ & $\begin{array}{c}0.32 \\
(0.11)\end{array}$ & $\begin{array}{l}71.10 \\
(8.44)\end{array}$ \\
\hline
\end{tabular}

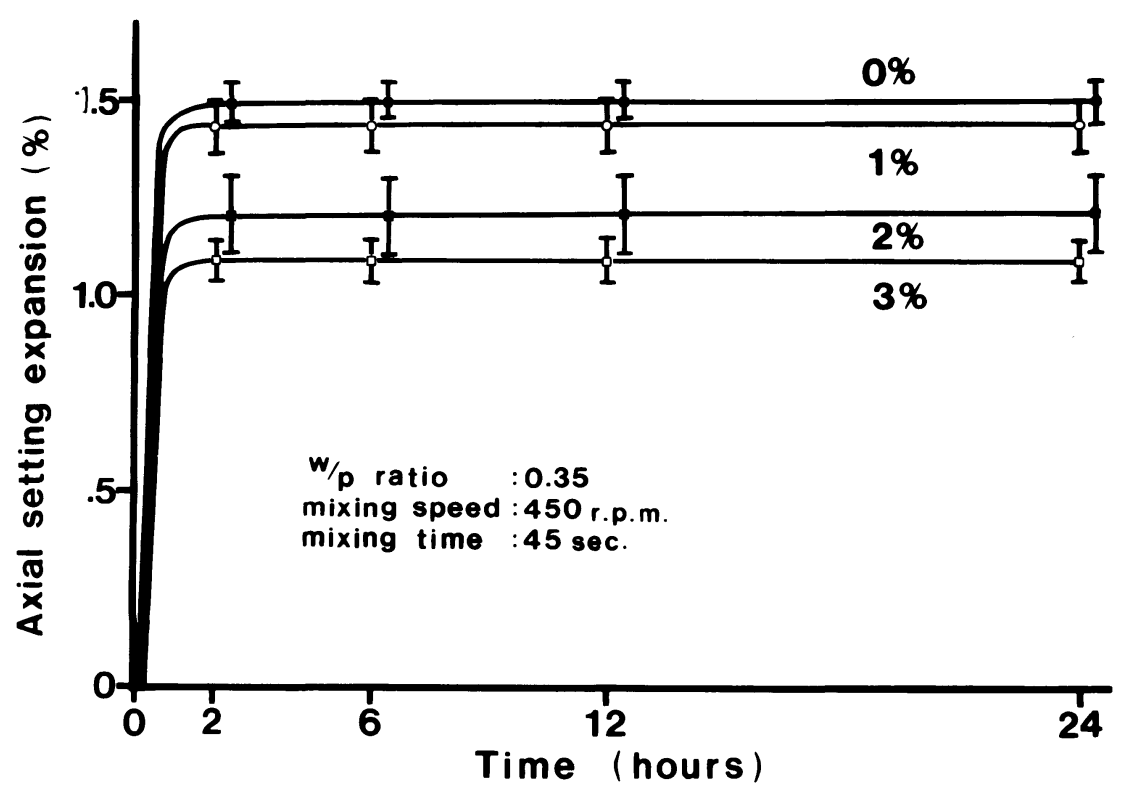

Figure 2 Setting expansion of investment mixed at $450 \mathrm{rpm}$ 


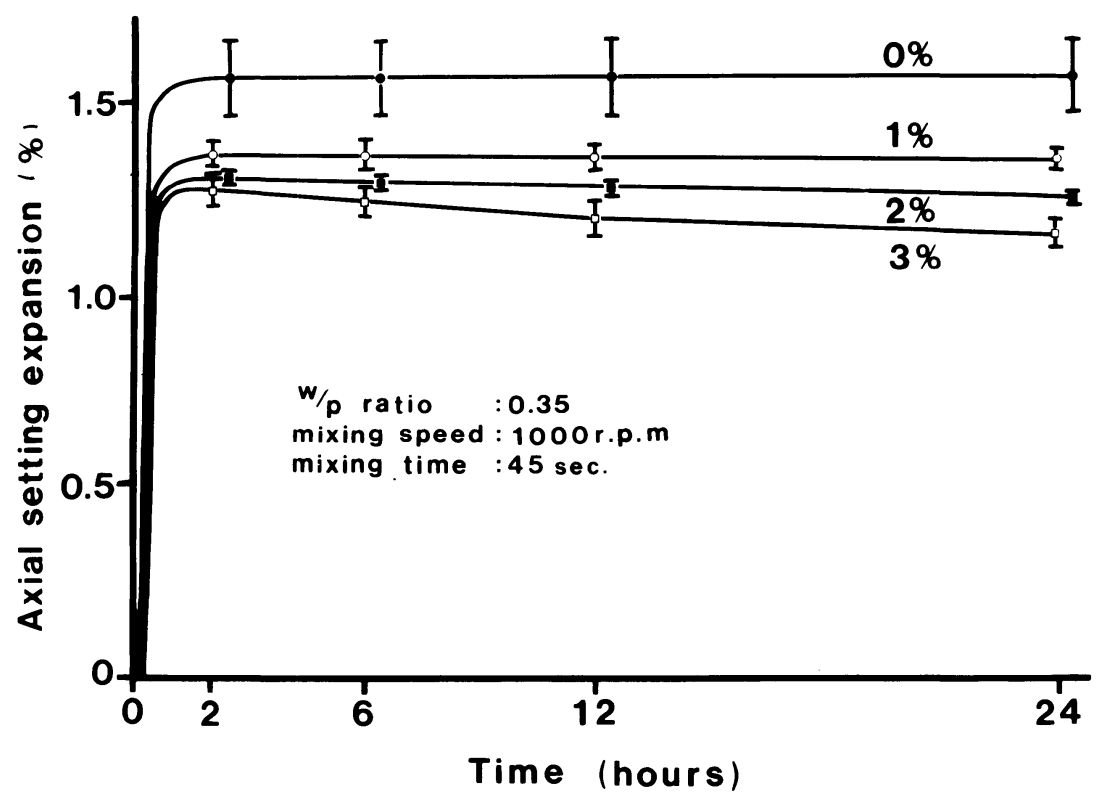

Figure 3 Reversal of setting expansion of investment mixed at $1000 \mathrm{rpm}$

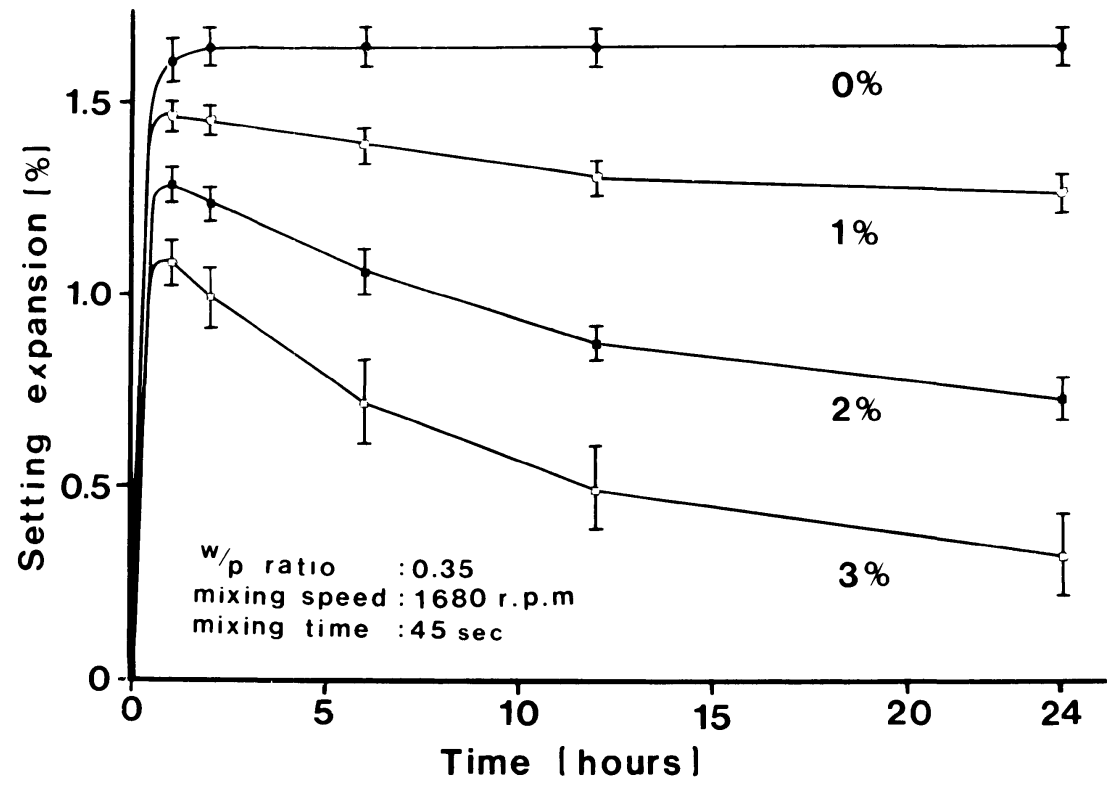

Figure 4 Reversal of setting expansion of investment mixed at $1680 \mathrm{rpm}$

ly. (Table II; Figure 3)

For samples mixed at $1680 \mathrm{rpm}$ : There was no reversal of setting expansion for samples which contained no CSD, but when the CSD concentration was increased to 1 , 2 , and $3 \%$, the E-max decreased by $13.8,43.6$, and $70.8 \%$ respectively. (Table II; Figure 4) 


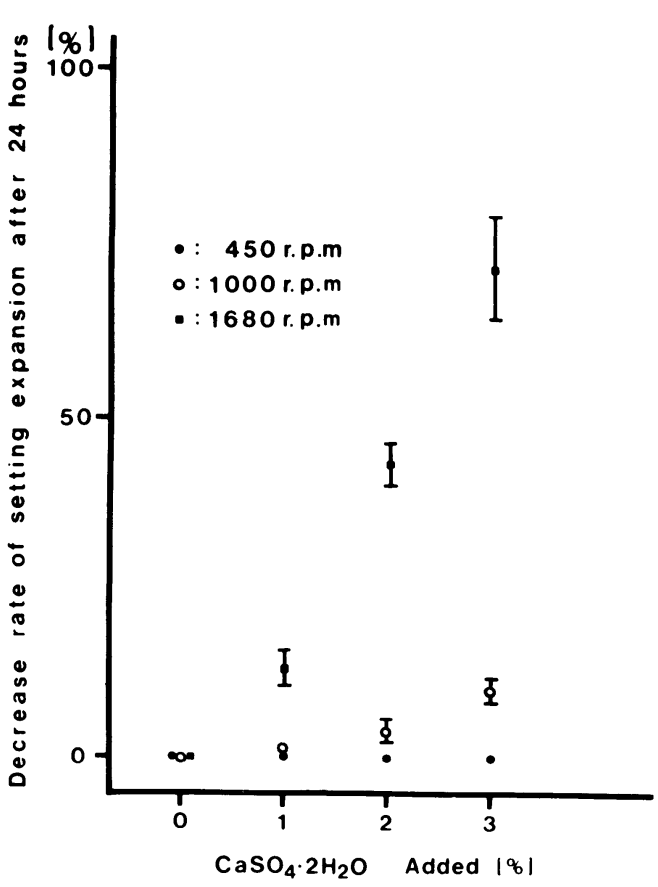

Figure 5 Percent decrease in 24 hour setting expansion as a function of $\mathrm{CaSO}_{4} \cdot 2 \mathrm{H}_{2} \mathrm{O}$ content and mixing speed

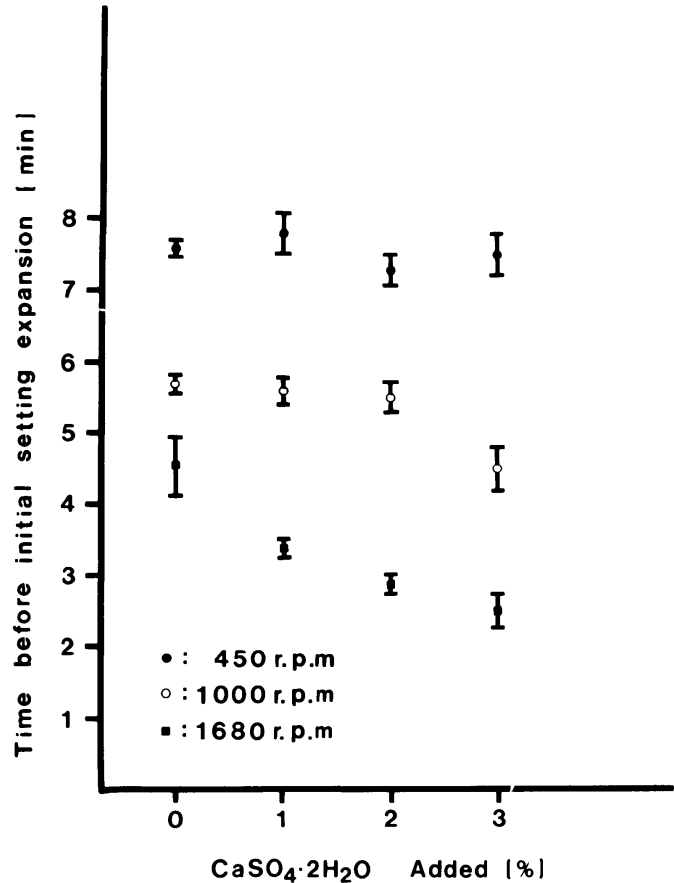

Figure 6 Effect of $\mathrm{CaSO}_{4} \cdot 2 \mathrm{H}_{2} \mathrm{O}$ content and mixing speed on time before detection of initial setting expansion

Figure 5 illustrates the relation between the decrease in E-max over $24 \mathrm{hrs}$. as a function of CSD concentration for each mixing speed. At all mixing speeds, there was a loss of E-max as the CSD content was increased, the magnitude of loss increasing with increasing mixing speed for a given CSD content.

Figure 6 illustrates the effects of CSD content and mixing speed on the time required to detect initial expansion $\left(T_{i}\right)$. For all investments mixed at $450 \mathrm{rpm}$., $T_{i}=7.5 \mathrm{~min}$. Increasing the mixing rate decreases $T_{i}$ for a given CSD concentration, and increasing the CSD concentration also decreases $T_{i}$ for a given mixing rate. The most rapid set ( $T_{i}=2.5$ minutes) was achieved in those investments containing $3 \%$ added CSD and which were mixed at $1680 \mathrm{rpm}$.

Figure 7 illustrates the effects of CSD content and mixing speed on the time required to achieve maximum expansion $\left(T_{E-\max }\right)$. At all mixing speeds, $T_{E \cdot \max }$ decreases with increasing CSD content, and for a given CSD content, $T_{E \cdot \max }$ decreases with increasing mixing speed. This is likely the result of additional nuclei of crystallization produced by more rapid rate of mixing.

Figure 8 shows the correlation the time required to achieve a maximum expansion $\left(T_{E-\max }\right)$ with the degree of actual percent loss of setting expansion. In logarithm-logarithm, there is a strong correlation between these values. The samples which set most rapidly also showed the greatest loss of setting expansion after $24 \mathrm{hrs}$. 


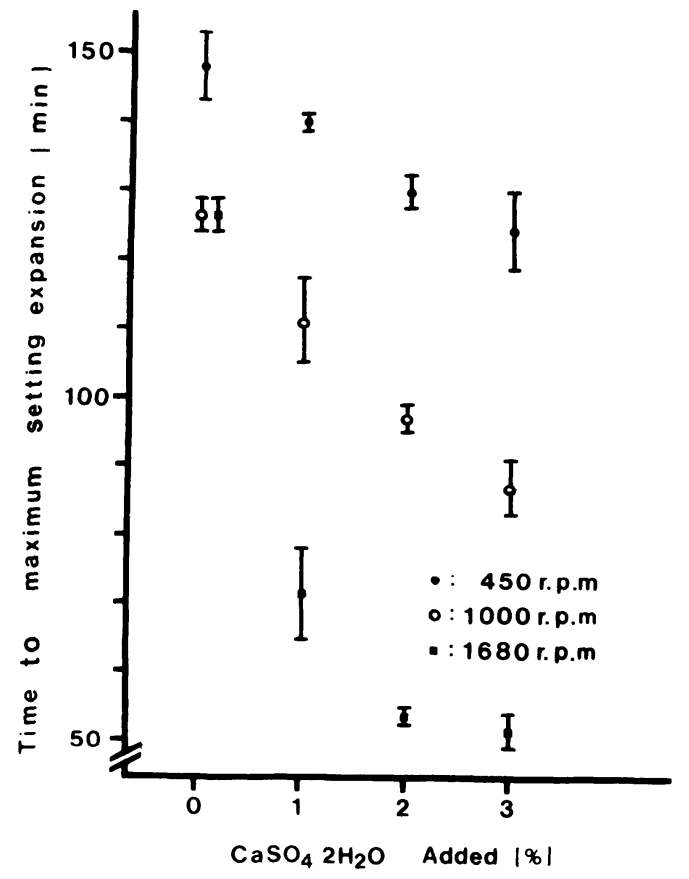

Figure 7 Effect of $\mathrm{CaSO}_{4} \cdot 2 \mathrm{H}_{2} \mathrm{O}$ content and mixing speed on time required to achieve maximum setting expansion

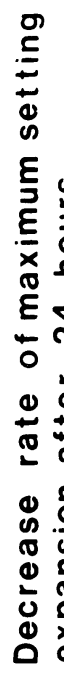

$$
|\%|
$$$$
100-1
$$

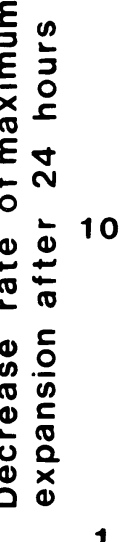

$1+$

$$
r=-0.935
$$
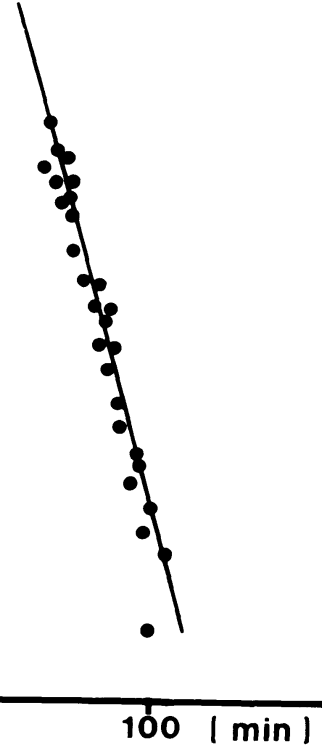

Time to reach maximum setting expansion

Figure 8 Logarithmic correlation plot of $T_{E-\max }$ vs. loss of setting expansion 


\section{CONCLUSION}

The reversal of the maximum setting expansion of gypsum-bonded investment was observed when CSD was added to the investment and when high speed mixing was employed. The degree of loss of setting expansion appears to be strongly correlated with those factors which lead to rapid set of the investment, although the specific mechanism for loss of expansion is not known.

\section{REFERENCES}

1) Fukui, H.; Lacy, A.M.; Isomura, M. and Hasegawa, J.: Reversal Setting Expansion of GypsumBonded Investments. Part I: Effect of Mixing Rate, Aichi-Gakuin J. Dent. Sci. 20: 144-149, 1982.

2) Fukui, H.; Lacy, A.M.; Ogita, K.; and Hasegawa, J.: Reversal of Setting Expansion of GypsumBonded Investments. Part III: Effects of Water/Powder Ratio, Aichi-Gakuin J. Dent. Sci. 21: 13-17, 1983.

3) Fukui, H.; Lacy, A.M.; Nakano, K.; and Hasegawa, J.: Reversal of Setting Expansion of GypsumBonded Investments. Part II: Effect of $\mathrm{CaSO}_{4} \cdot 2 \mathrm{H}_{2} \mathrm{O}$ Concentrations, Aichi-Gakuin J. Dent. Sci. 20: 303-306, 1982. 


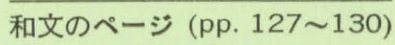

\title{
本号掲載論文の和 文抄録
}

\author{
$\mathrm{CaSO}_{4} \cdot 2 \mathrm{H}_{2} \mathrm{O}$ 添加による石こう系鋳型材の硬化時膨張 \\ の反転現象について
}

福井寿男，河合達志，紀藤政司，菊地元彦，長谷川二郎

愛知学院大学歯学部歯科理工学教室

石こう系鋳型材を $1680 \mathrm{rpm}$ の速度で機械練和した際 に発現した膨張が経時的に反転あるいは減少するととを 発見した。この原因は硬化時間の短縮が影響していると 考えられた。

そこで, 硬化時間の促進として作用する $\mathrm{CaSO}_{4} \cdot 2 \mathrm{H}_{2} \mathrm{O}$ の添加と混和速度を組合せて硬化時膨張の反転現象を検 討した。

最大硬化時膨張の反転は $\mathrm{CaSO}_{4} \cdot 2 \mathrm{H}_{2} \mathrm{O}$ が添加された 場合でしかむ $1000 \mathrm{rpm}$ および $1680 \mathrm{rpm}$ の高速で混和
されたときに起とる。そしてての反転率は $\mathrm{CaSO}_{4} \cdot 2 \mathrm{H}_{2} \mathrm{O}$ の量と混和速度に影㗽される。すなわち硬化時間を促進 する要因が硬化時膨張の経時的な反転に関与しているて とが判明した。 $3 \mathrm{~g}$ の $\mathrm{CaSO}_{4} \cdot 2 \mathrm{H}_{2} \mathrm{O}$ を添加し, 1680 $\mathrm{rpm}$ で混和したものは24時間後には最大硬化時膨張 值 が71\%減少していた。一方 $3 \mathrm{~g}$ の $\mathrm{CaSO}_{4} \cdot 2 \mathrm{H}_{2} \mathrm{O}$ の添加 でも $450 \mathrm{rpm}$ での混和では最大硬化時膨張の反転は出 現しない。

\section{タンニン・フッ化物合剂（HY 剂）を配合した 高銅型アマルガムの物理的性質 \\ 中井広之，鈴木一臣，入江正郎，長山克也*，橋本弘一* \\ 岡山大学迷学部菌科理工学講座 \\ *城西歯科大学歯科材料学講座}

タンニン・フッ化物合剂 (HY 剂) 配合単一組成型高 銅アマルガムの物理的性質と12 个月間浸水の及ぽす影響 を検討した。フッ化錫配合の削片状低銅型アマルガム （市販品）並びにフッ化物を含まない削片状低銅型アマ ルガムと単一組成型高銅アマルガムを刘照として用い た。HY 剂の配合が高銅型アマルガムの物理的性質に及 ぼす影響についてみると, $0.5 \mathrm{wt} \%$ までは著明ではない が, $1.0 \mathrm{wt} \%$ ではクリープを除いて著明であった。水中 浸漬後では径方向引張り強さの低下が著明であったが圧 縮強さの低下はそうではなく, クリープは変化しなかっ
た。一方, フッ化錫含有削片状低銅型アマルガムは水中 浸漬後, 物理的性質はいずれも著明に低下した。微細構 造の変化は高銅型アマルガムについては含有されていた HY 剂の脱落による空隙の発生以外にはみられなかった が，低銅型アマルガムの方はフッ化錫の脱落による空隙 の他に $\gamma_{2}$ 相の腐食や溶解の様子がみられ, 物理的性質 の低下と関連していた。これらの所見は対照として用い たフッ化物を含有しない低銅型アマルガムについても同 様であった。 